\title{
極低温大容量送電線が導入された都市電力 系統に関する一考察
}

$\begin{array}{llllll}\text { 正員 鬼 } & \text { 頭 幸 生 } & \text { (名古屋大) } \\ \text { 正員 松 } & \text { 村 年 郎 } & \text { (名古屋大) } \\ \text { 正 員 加 藤 } & \text { 宏 明 } & \text { (名古屋大) } \\ \text { 准 員 } & \text { 早 } & \text { 川 直 樹 } & \text { (名古屋大) }\end{array}$

\section{1.まえがき}

将来, コンピュータを中核とする高度情報化社会が 発展するに従って，電気エネルギーは，二次エネルギー としての価值を高めてくると考えられる。しか子質的 には，従来上り高いことが求められると同時に，量的 には単に大きさのみでなく，密度の高い多様な消費形 態に対処していかなければならない動向にある。しか し，都市中心部一の送電证従来の $154 \mathrm{kV}, 275 \mathrm{kV}$ 級 送電網だけでは次第に行き詰まる傾向にある。それは 土地の余裕が既になく，また，環境美観などの面から 社会が電気工作物の設置を容認する余地む少なくなっ てきているからである。てれ客根本的化解決する一つ の技術上して極低温大容量送電線を導入することが考 えられる。ここで極低温大容量送電線には極低温抵抗 ケーブルおよび超電渞ケーブルが考えられているが, いずれす 1 回線, $20 \sim 100 \mathrm{~km}$ で 3,000 5, $000 \mathrm{MW}$ の送電を可能とするすのである ${ }^{(1)}$ 。

本論文ではそのように大電力が集中する線路を高機 能を具備した都市地域に適合した形で導入する方策を 探り，大容量電力輸送のあり力について次の二つの視 点加ら概念的な检討を行なっている。

（1）極低温送電線の上うな高密度大容量線路之, 多数の変電所間を結ぶ在来ケーブル線路との最適な系

A Study on a Configuration of an Electric Power System with a Cryoresistive High Power Cable in a Future Large City. By Yukio Kito, Member, Toshiro Matsumura, Member, Hiroaki Kato, Member, Naoki Hayakawa, Associate (Faculty of Engineering, Nagoya University).

鬼頭幸生：正員，名古屋大学工学部常気学稓

松村年郎：正員，名古屋大学工学部電学科

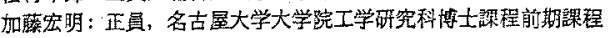
(祭在, 住友需工)

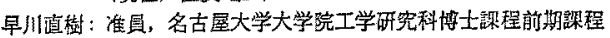

統構成の考え方。

（2）高密度大容量線路事故時の代替翰送路を確保 する系統構成之その操作。

具体的には，筆者らが在住する名古屋市程度の規模 の都市に対する約 $1 / 4$ 世紀先におけるモデル都市を想 定し，予想需要分布汇対して送電系統を設定した。こ の時期に扔いては，従来ケーブルの増設はその設置ス ペースなどの制約のため困難になるととが想定でき， $275 \mathrm{kV}, 1$ 回線 $3,000 \mathrm{MW}$ 程度の送電容鼠を持つ極 低温送電線の導入が有効と考えられる ${ }^{(2)}$ 。

ここでは，大都市に隣接する臨海大容量火力発電所 と，都市中心部変電所との間に液体窒素冷却の極低温 抵抗ケーブルを設置するすのとして検討を進めた。を の上うな火力発電所は脱石油のため LNG な゙を燃料 とすることが多くなり，その低温を利用して作られる 液体窒素を冷媒として利用できるからである。るれに 加えて，極低温抵抗ケーブルは超電導ケーブルより先 化実用化されると考えられている( ${ }^{(3)}$ 加らであある。

極低温送電線は高価であるので，従来の送電線のよ うに，それを 2 回線設置することを避ける考元方を探 る。しかもその事故時においても都市中心部への電力 供給を維持できるようにする。すなわち，極低温送電 線の予備力としてもう一本の極低温送電線を用意して おく（2 回線構成とする）ととなく，以下に示すよう 任, 従来送電系統全体の送電余裕を極低温送電線事故 時の送電予備力とすることができるのではないかとい う考元加たをこで提案したい。これは，発電機の場 合一台が停止したとき，その分を他の発電機一台で目 担するのではなく，系統全体の全発電機で分散して直 担するのと類似の考元かたを系統構成に導入したるの である。 
このような考えかたに基ついて，次のような系統構 成わよび系統操作を提案する。(1) 平常時には，中心 部へ極低温送電線で導入した電力を周辺部へ逆送する 形热の系統構成を採る。(2) 要所に母線形態を分割母 線暴系統受電方式とする変電所を設け,すべての送電 線に常時負荷電流が流れているようにするとともに， 日本の電力系統が伝統的に採用している放射状形態を 維持する。(3)極低温送電線事故時には，それまでそ れで送電していた電力を $275 \mathrm{kV}$ および $154 \mathrm{kV}$ の従 来両系統に一時的に分散して負担させ，既成の 2 電圧 階級のケーブル線路の有效利用を行なう。(4)当然こ れらは過負荷になるところあでてくるのでこれを解消 するための系統切り換えを行なう。

上述のモデル系統において, 最大負荷に対する潮流 を平常時および極低温送電線事故時の二つの場合につ いて求的だ。その結果, こてで提案する采統構成, 系 統操作䎲より大容量高密度電力輸送が可能であること が示された。更に, 分割母線異系統受電方式の変電所 の位置を変化させて，そのときの送電損失の大きさと 事故時に枋ける系統操作の煩雑さとの関連を検討した ところ，送電挰失のみの観点から，最適な系統構成が 決まるのではなく，事故時における系統操作回数をも 評価の対象に入れなければならないととが明確となっ た。

\section{2. モデル系統}

$\langle 2 \cdot 1\rangle$ 大都市送電系統の模式化 昭和 56 年の名 古屋地区における電力需要密度分布などの実態調査拉 よび電力関係者の将来計画をもとにして, 約 $1 / 4$ 世紀 将来（昭和 85 年）を見越し, 名古屋地区程度の規模 を想定し，典型的な都市送電系統の模式化を試みた。

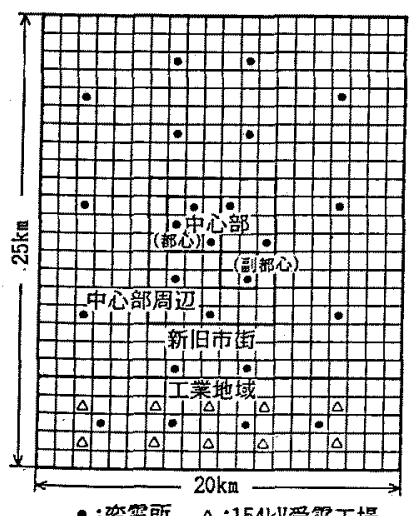

因 1 需要分布加引みた变電所配置の模式化

Fig. 1. A model distribution of electric power substations in a future large city.
表 1 昭和 85 年 $(25$ 年後) における電力需要 予想 (最大電力)

Table 1. Forecast of electric power demand in 2010 A.D. (25 years later) (Maximum load).

\begin{tabular}{|c|c|c|c|c|c|c|c|}
\hline & \multirow{2}{*}{ 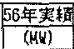 } & \multicolumn{2}{|c|}{ ケースI } & \multicolumn{2}{|c|}{$r-22$} & \multicolumn{2}{|c|}{$r-23$} \\
\hline & & 婶变 $(\chi /$ 年 & 覆翌 (MW) &  & 霍要 $(\mathrm{HO})_{j}$ & 伤 & 䙵要 (MV) \\
\hline 中心部 & 470 & 2.2 & 900 & 3.0 & 1.200 & 3.0 & 1.200 \\
\hline 中心新㳻辺 & 490 & 2.3 & 950 & 3.0 & 1,200 & 3.0 & 1,200 \\
\hline 莠汨节洼 & 1.720 & 2.1 & 3.150 & 2.5 & 3,600 & 3.0 & 4,050 \\
\hline 美地盛 & 1.000 & 2.1 & 1.300 & 3.0 & 2,400 & 4.0 & 3.100 \\
\hline 合計 & 3,680 & - & 6.800 & - & 8.400 & - & 9.550 \\
\hline
\end{tabular}

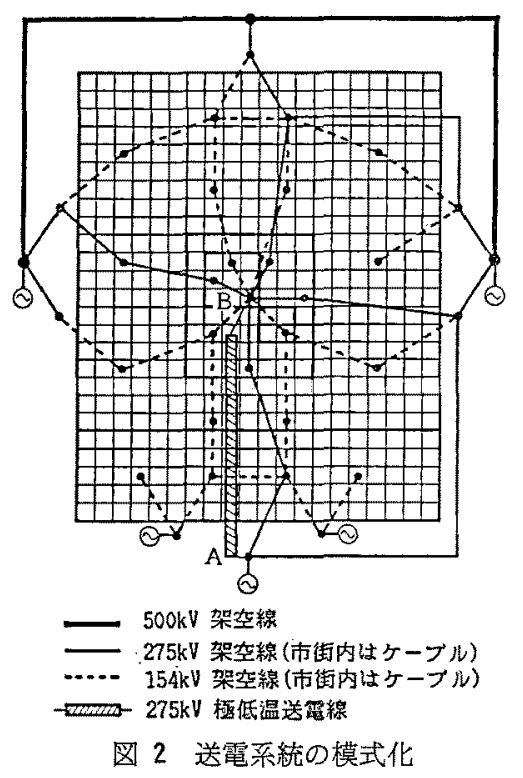

Fig. 2. A model power system in a future large city.

すなわち图1に示すように都市を $1 \mathrm{~km}$ ごよに $20 \times$ 25 の方眼に区切り，それらを「中心部」，「中心部周 扨」「新旧市街」拉よび「工業地域」の 4 種類に分け る。乙の程度の都市規模においても将来「中心部」と しては都心，副都心の二つが存在するとととする。

それぞれの区域での電力需要の予想を一義的に決め ることは非常に難しいが, 表 1 の上うに 3 種のケース を想定してみた。ケース 1 は昭和 56 年の時点にお お る電力関係者の将来予想を 85 年まで単純に外㨉した あので，地域全体の最大需要は $6,800 \mathrm{MW}$ である。 ケース 2 は高度情報化社会としての機能が進展し，大 形計算機やロボットの導入が進み, 全体としてケース 1 より電力需要が大きく增加した場合で, 最大需要は 8, $400 \mathrm{MW}$ である。ケース 3 はケース 2 の傾向が更に 強調された場合で, 最大 $9,500 \mathrm{MW}$ 亿達するもの で，極端な例といえよう。

図 1 亿おいて・印悴電所の位置である。実態調查 に基づて，中心部で密集し外側に向加て次第化散 
らばるように配犆した。1変雪所あたりの容量は，平 均で $300 \mathrm{MW}$ 程度となるようにした。

このような需要分布内に存在する変電所間を送電線 で結んだすのか溷 2 の実線出よび破線である。同図で 你都市走とりまく $500 \mathrm{kV}$ 外输線加ら, 超高殴変電所 を経て $275 \mathrm{kV}$ 招よび $154 \mathrm{kV}$ の架空送電線およびケ 一ブルが杲西南北 4 方向から都市内に引き込まれてい る。都市中心部技よび周召部の変電所には送電線が少 なくと向2方向から延びてきているむのとする。との 上うな都市送電絧の形態は机上において何種類も想定 できるが，電力采統というすのの特性上，現代から一 種の進化した形を考えるのが妥当で，ててで提案して いるこデル系統は，電力関保者の将来計画加ら著しく 造脱したものではなく，そ㧈に基づいて議諭を進める のは有益であると考える。

\section{$\langle 2-2\rangle$ 極低温送電線を含む系統 前節，図 2 で} 示した在来送電線のみの系統では本諭文で考えてい る25 年後における都市内の需要をまかないきれず， より大容量の送電線を都市中心部にまで導入すること が必要となるう。しのような送電線としては, $500 \mathrm{kV}$ の通常ケーブルあるいは $275 \mathrm{kV}$ の極低温送電線の 2 種類が考えら机る。両者を比較すると，500 kV ケ一 ブルは都市空間注打る多条のケーブル設置スペース の不足, 分路リアクトルの容量增加などの面で不利 で，冷却技術や設備の高度化が必要となるにしてす他 に問題が少ない $275 \mathrm{kV}$ 極低温送電線の方が係れてい ると思われる。し加も昇生，降仕の必要がないため， $500 \mathrm{kV}$ 用变王器の空間や大きな絶縁間隔が不必要亡 なり，ての分を極低温送電線の朎却スペースにあてる 亡考えれば十分相殺され，乙の点加ら屯極低温送電線 が有利であると思われる。

そこで，極低温送電線の設置箇所亡して，本論文で は，大都市近郼の臨海大容量火力発電所 (図 2 中，A) から中心部（図 2 中，B）まで (全長 $20 \mathrm{~km}$ 程度） 例任取って考える。その送電容量 $3,000 \mathrm{MW}$ とす る。乙の程度の送電容量から極低温抵抗ケーブルの㑃 位性が現われてくる ${ }^{(2)}$ 。中心部へ導入された 3,000 MW に達する電力はそこでのみ消費されるのではな く，中心部加ら外側に向けて逆送さ机，功なり広い地 域の需要を一挙にまかなうととができる。

\section{3. 分割母線異系統受電方式 (突合せ方式)}

日本においては，送電系統がループ状になるととを できる限り避け，放射状を形成して需要地まで延びて いる。こてでの検討もそれは尊重するものとして進め る。図 2 の送電網に㧍いて放射状を維持し, なお，極

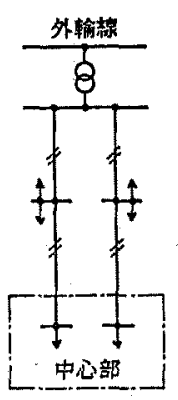

(a) 従来の形 (b) 切换受露

万式

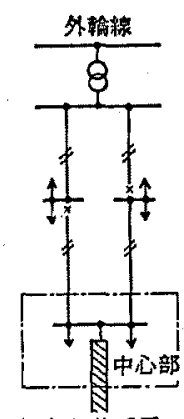

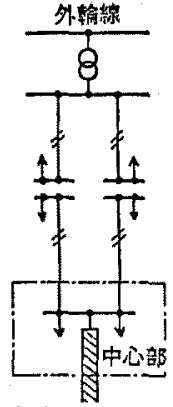

(c) 分割母辣

供系統役籍方式

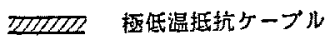

一2回線邫表才

图 3 都市中心部から周辺へ電力を逆送する形驡

Fig. 3. A sending back system of electric power from the center of a city to the surrounding areas.

\section{表 2 受電方式の利害得失}

Table 2. Advantages and disadvantages of power receiving methods in substation.

\begin{tabular}{|c|c|c|c|}
\hline 受霆夸侙 & 系祛切摁操拃 & 器電線の利用度 & 送䨤提失 \\
\hline 切提 & 權成が留梎で & 平常時には使われ & \\
\hline 要電方式 & ミスが少ない & $\begin{array}{l}\text { ない送管線が多数 } \\
\text { 存在するる }\end{array}$ & ふなる \\
\hline 割㹂線 & 楧成が被雑で操作 & 平常洔でもほとん & \\
\hline 翟系統 & ミスをすると系統 & どすべての送霍線 & くなる \\
\hline 溌霞方式 & がルーフフ状になる & が利用される & \\
\hline
\end{tabular}

低温送電線で中心部に導入された巨大な電力を周辺へ 逆送するためには，平常時には適当な変電所において 線路を切り離しておくことが必要である。因 3 (a)が 従来形の都市送電線の形態であるとすると, 同図(b) および $(\mathrm{c})$ は極低温送電線導入時の形態で，しかむ中 心部から周辺部へ電力を逆送している形である。

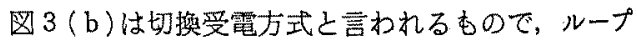
となる送電線は一端の変電所で母線から切り離して き，平常時には潮流が流れない上うにしておく。图3 （c）は分割母線異系統受電方式と言和れ，変電所にお いて母線を複数に分割して拈き，異系統（都市中心部 加ら電力を逆送している系統と外翰線加らの系統）加 らの送電線を別々の母線で受電する方式である。

画方式の特徽や利害得失を表 2 に比僌した。現在で は多少送電線の利用率は鲳くて屯, 誤操作の少如い切 換受電方式が主保用いられている。しかし，一部では ケーブルの送電容量の不足という理由から，現在でも 母線を分割し，それぞれ異なった系統から受電する方 式も行なわ机ている。将来，極低温送電線が都市中心 部に集中的に大電力を送り込むようになり，周迅部へ 電力を逆送するときの突合せ変䉓所には，ケーブルの 
有効利用を図るためにもこのような分割母線巽系統受 電方式を積極的に採用した方が良いと考元る。本研究 における系統構成ではこの方式を中心检討を行なう あのとする。

\section{4. 極低温送電線導入時の電力潮流}

〈4.1〉、需要分布 昭和 85 年の名古屋およびその 周辺地域におりる需要分布予想のうち表 1 のケース 2 を検討の対象とする。最終的な需要は名古屋地区全体 で 8,400 MW に達すると予想されている。しかし， 「工業地域」では発電所から需要家まで変電所を介さ ずに直接送電している例が多いので, 表記 $2,400 \mathrm{MW}$ のうち半分の供給についてはそのような形態を拯るあ のとした。従って，図2の系統では全体として 7,200 MW の需要をまかなっているものとした。

$\langle 4 \cdot 2\rangle$ 送電容量 平常時, あるいは事故時の潮 流を計算するに先立って，本節ではケーブルを主体と する都方送電線の送電容量について本研究で检討した 目安を与えておくとととする。結論的にまとめたのが

表 3 各送電線の技術的送電容鲳

Table 3. Technical capacities of electric power transmission lines.

\begin{tabular}{|c|c|c|}
\hline 这電楾 & 權成 & 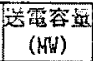 \\
\hline $500 \mathrm{kV}$ 架空線 & TACSR $810 \mathrm{~mm}^{2} \times 4.2$ 回䄸 & 4,500 \\
\hline \multirow{3}{*}{ 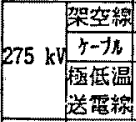 } & TACSR $410 \mathrm{~nm}^{2} \times 4,2$ 回線 & 1,400 \\
\hline & 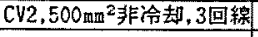 & 1,000 \\
\hline & 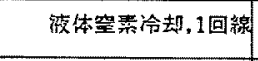 & 3,000 \\
\hline \multirow[t]{2}{*}{$154 \mathrm{kv}$ 架空總 } & ACSR 610 an $^{2} \times 1$,2回線 & 450 \\
\hline & 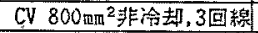 & 450 \\
\hline
\end{tabular}

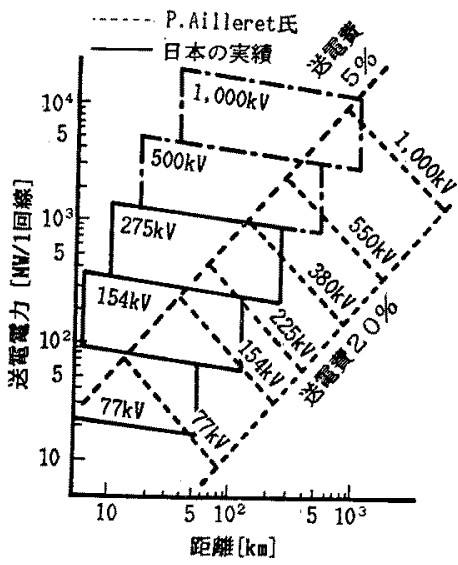

図 4 架空線の送電電力の実績之 Ailleret 氏の評価

Fig. 4. Actual transmission capacities of overhead lines in Japan and estimated ones by $P$. Ailleret.
表 3 である。同表の送電容量の見穑りは次のように行 なっている。因 4 は日本の電力会社に扰ける实際の架 空送電の実績を送電距離に対してプロットし，各電圧 階級別に領域にまと的たので，500 kV および 1,000 $\mathrm{kV}$ については，275 kV までの領域から外插して想 定したあのである。破線は，1960年に発表された Ailleret 氏の見積である(4)。乙れをみると各領域の長 距離側の送電容量蚛両者一致している。しかし, 各領 域の短距離側の送電距離側において日本はかなり控元 目な値をとっていることがわかる。こてで検討してい る都市送電では短距離送電であるから，275 kV 架空 線については 1 回線 $700 \mathrm{MW}$ 之読及取り，2回線で 2 倍の $1,400 \mathrm{MW}$ とみなしている。 $500 \mathrm{kV}$ 扣よび $154 \mathrm{kV}$ 架空線については $275 \mathrm{kV}$ の値を基海電压の 2 乗に比例するとして定めた。これらの值は図4の日

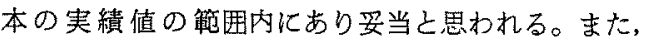
$275 \mathrm{kV}$ および $154 \mathrm{kV}$ 改良 CV ケーブルの送電容量 については電力関係者の将来計画加定的ている。

$\langle 4 \cdot 3\rangle$ 電力潮流 名古屋地区全体の需要加 25 年後 に 8,400 MW に達し，そのうち中心部および中心部 周辺での合計が $2,400 \mathrm{MW}$ とすれば， $3,000 \mathrm{MW}$ を 極低温送電線を通じて中心部へ直接導入する之，中心 部捅よび中心部周辺の負荷をすべてまかなうことがで き, 更に一部は新旧市街地まであ逆送して電力を供給 することができる。ての点においてお，従来の外輪線 から電圧階級を落しながら内部へ電力を送電したのと は異なる発想である。この中心部から外向きに延びて くる線路之，外輪線から内向き代延びてくる線路とを 分割母線異柔統受電方式によって切り離しておく点 （突合せ点）は中心部周辺から郊外にかけて存在する 変電所に直くのが適していると考えられる。

因 5 にその時期におりる最大負荷時に対応して，極 低温抵抗ケーブルの潮流が $3,000 \mathrm{MW}$ の場合の系統 構成を示す。ここでは極低温抵抗ケーブルに送電容量 いっばいの潮流がのるように突合せ変電所の立置およ び負荷配分を調整している。同図では以下の検討に必 要となる変電所にのみ番号をつけ，主だった送電線の 潮流 (100 MW をベースとした pu 表示)を示してお く。変電所\# 1 と変電所 \#2 結 2 回線 2 ルートとしている。乙れは変電所 \#1，\#2, \# 3 がそれぞれ都市外周に存在する超高生大容量変電 所付対し，ととへは $275 \mathrm{kV}$ の送電線が外輪線とし て延びているととによる。

同図では， $275 \mathrm{kV}$ 系統の变電所が $154 \mathrm{kV}$ 系統の 变電所上りも多くの負荷を取るように配分してある。 また，負荷の力率は一律化約 0.9 と仮定し，(有效電 


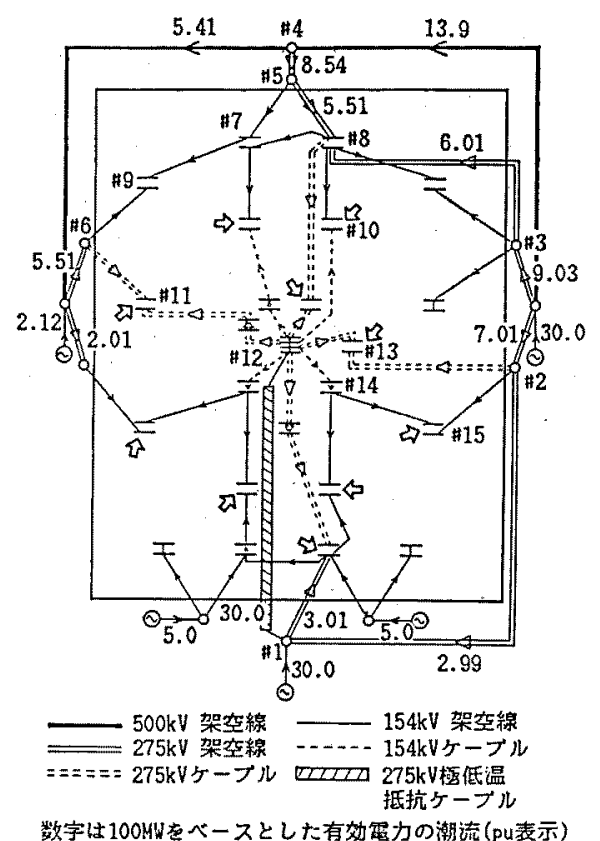

困 5 極低温抵抗ケーブル導入時の送電系統 および潮流

Fig. 5. A configuration of the power transmission system with a cryoresistive power cable and result of load flow analysis.

力) : (無効電力) $=2: 1$ とした。 $\left(\cos \phi=\cos \left(\tan ^{-1} 1 / 2\right)\right.$ $=0.894$ )

图 5 は一義的なものではないかのどとき印象を与え るが, 系統構成が㰮史的にある程度与えられ, 各変電 所の設備容量にそれぞれの電圧階級において，大きな 相違がないとすれば，潮流はおよそ四 5 の通りのもの となる。また，既設のケーブル系統を有效に利用する ために, 最上位のケーブル電王階級 $275 \mathrm{kV} レ$ レ゙ルの

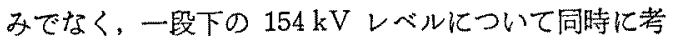
えることに特徴がある。

分割母線を持ち，都市中心部加ら逆送されてくる電 力と外輪線から送られてくる電力とを受電する変電所 (以下，簡単のため突合せ変電所と呼ぶ。図5では白 技きの矢田で示している) を变えることによって極低 温抵抗ケーブル上の電力潮流の大きさは変わる。その 大きさを $3,000 \mathrm{MW}(30.0 \mathrm{pu}), 2,700 \mathrm{MW}(27.0 \mathrm{pu})$ および $2,400 \mathrm{MW}(24.0 \mathrm{pu})$ としたときの送笔損失の 変化を表 40 左加ら 2 列目，平常時送電損失欄に pu 表示で示す。ここで，30.0 pu の場合は $275 \mathrm{kV}, 154$ $\mathrm{kV}$ 系統と兵合せ変電所を最香外側にとり，図 5 の 場合に相当する。これに対し $27.0 \mathrm{pu}$ および $24.0 \mathrm{pu}$

\section{表 4 送電挜失内切換数}

Table 4. Total transmission power loss and the number of operations in the model system.

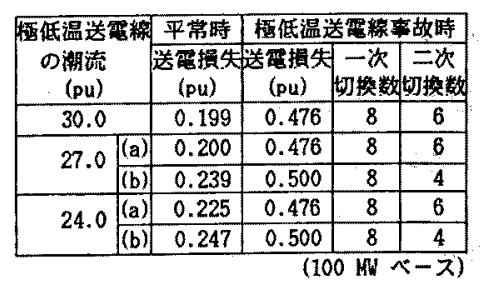

の場合は表 4 でそれぞれ(a) および(b)の2ケースに 分類してある。このうち(a)のケースは $275 \mathrm{kV}$ 系統 で逆送する籁用を $30.0 \mathrm{pu}$ の場合と比へて狭くした 場合，（b）は $154 \mathrm{kV}$ 系統で逆送する範囲を䧆くした 場合である。

同じ潮流を極低温抵抗ケーブルに乗せた場台につい て，ケース( a )と(b)とを比較すれば，ケース(a)の 方が送電損失が小さなっってい。これは次の理由に よる。ケース(a)の $275 \mathrm{kV}$ 系統で逆送範囲を狭くし て極低温送電線に乗せる潮流を少なくした場合，その 减少分を外輪線からの $275 \mathrm{kV}$ 送電線に負担させるこ とになる。他方，ケース(b)の場合は外輪線からの $154 \mathrm{kV}$ 送電線に負担させるととになる。このため, ケース（a）の方が全体としての送電損失が小さくな り，有利である。いずれにせよ，てのような平常時に おける送電損失の大きさという観点からは表 4 から極 低温抵抗ケーブルに大きな潮流をのせた方がよいが, 最適な系統構成を考えるためには, 次章で述べる事故 時の系統操作の煩雑さ秀えなりればならない。

\section{5. 極低温送電線事故時の代替系統構成}

〈5.1〉基本的考え方極低温送電線は恐らくか なり高価なすのであるために, 従来のように事故に菕 えて2回線を設置することは避けて，1回線の能力を

表 5 極低温送電線事故時の代替送電

Table 5. Conception of temporary transmission method at the failure of the cryoresistive power cable.

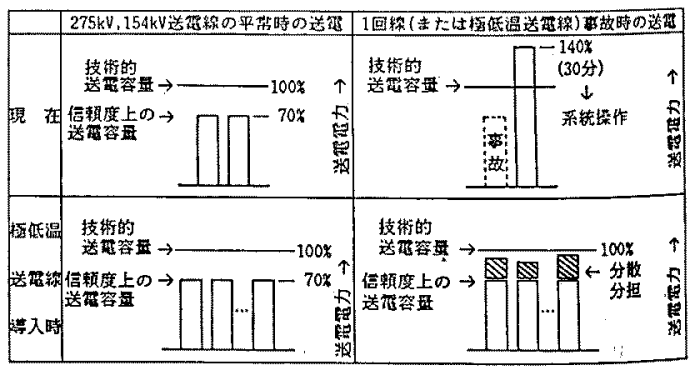


すべて引き出す方が有效ではないかと考える。他方， 従来加形成されている図 2 亿描加れた $275 \mathrm{kV}, 154$ $\mathrm{kV}$ のケーブル系統はすべて 2 回線以上から成り，平 常時ならびに事故時の運転は表 5 亿示すように計画さ れている。すなわち，平常時には各回線は技蒲的侸 電し得る笔力（以下，技術的送電容量）の70\%（以 下, 信頼度上の送電容量) で送電している。1 回線事 故時には他の 1 回線が $140 \%$ の電力を約 30 分間送電 する。この間に系統の切り換えが行なわれ，過負荷分 を解消していく。並行 2 回線で 1 回線遮断時に他加ら 切り換え送電のできない場合に対して，送電容量は通 常十分余裕を見込んであり，それは 2 回線送電線の信 頼性を確保するために必要である。とのような考えか たで現在この程度の余裕をすって運用されている。

極低温送電線が導入された場合に，それが故障を起 こしたときは多数の $275 \mathrm{kV}, 154 \mathrm{kV}$ ケーブルの技術 的送電容量之信頼度上の送電容量との差の $30 \%$ の送 電能力を利用して，平常時江極低温送電線で送電して いた電力妢を通常ケーブルのみで一時的に分散して分 担し，代替送電ができるのではないかと考える。この 場合, $275 \mathrm{kV}$ 送電線を優先的に用いるが，それだけ で代替送電が維持できない場合には，一階級下の 154 $\mathrm{kV}$ 送電線を活用する。但し, 更にその期間に通常 のケーブル事故が重なった場合には一部停電を発生す ると予想されるが，それは現段階では考えないことに する。また，極低温送電線脱落直後の系統の過渡動摇 については考えず，定常的に代替送電が可能かを諭 ずる。これを次節に示す。

$\langle 5 \cdot 2\rangle$ 一次, 二次系統切換極低温送電事故時 の在来系統による電力代替輸送は, 図 5 亿打ける都市 中央の変電所 (\#12)の 4 母線を切り離して，275 kV 系統の突合せ変電所の分割母線を閉じることにより行 なう。この操作を一次切換と呼ふととにする。また， 一次切換の結果，技術的送電容量を越える送電線が現 れた場合，更に系統切換を行なうことにより各送電線 の潮流を技術的送電容量内に㧕える。この操作を二次 切換と西ぶことにする。

潮流が $30.0 \mathrm{pu}$ 存在していた極低温抵抗ケーブル が全停した場合について，主な送電線の一次切换後の 潮流を図 6 亿示す。同図の数值は $100 \mathrm{MW}$ をベース とする pu 表示で示しているが，過負荷であるかどう

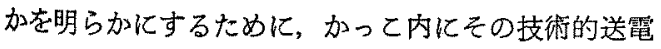
容量侪する比率を示しておく。数回のシミュレーシ ョンの結果, この例は一次切換数が 8 筫所となった が，これ以下の切换数とするケースは見出せなかっ た。具体的には，極低温抵抗ケーブルの系統からの除

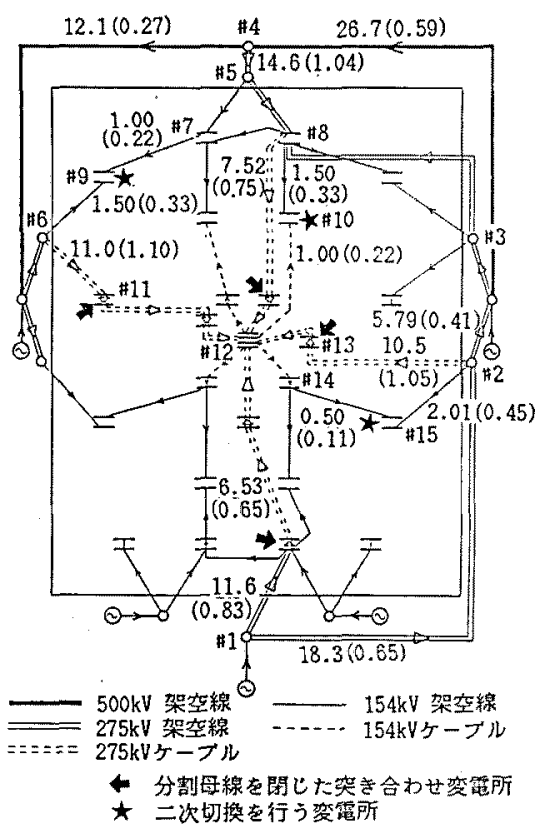

図 6 極低温抵抗ケーブル事故時の一次 切換後の送電系統招上び潮流

Fig. 6. A configuration of the power transmssion system after dropping off of the cryoresistive power cable.

去 (操作数 1 ) 後, 変電所 $\# 12$ 亿占ける 4 本の母線の 切り離し(同 3), 图6で矢印で示した 4 箇所の変電所 での分割母線接続（同4）という系統操作を行なう。 従って，一次切換数は $1+3+4=8$ となる。極低温抵 抗ケーブルの潮流が $27.0 \mathrm{pu}$ および $24.0 \mathrm{pu}$ の場合 であ同様に一次切換数は 8 䇢所が最少であった。

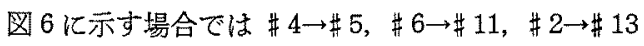
の3本の送電線で技衍的送電容量を越えている（同图 のかっこ内の数字が 1 以上) ため, この 3 本の送電線 に対して以下のように二次切換を行なう。てれは二次 切換数の最む少ないものである。

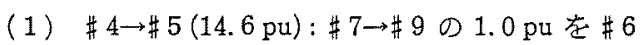

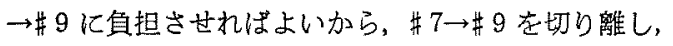
変電所＃90分割母線を接続する。徒って，二次切換


になる。

(2) $\# 6 \rightarrow \# 11(11.0 \mathrm{pu}): \# 12 \rightarrow \# 10$ の $1.0 \mathrm{pu}$ を $\# 8 \rightarrow \# 10$ 亿負担さ甘ればよいから，\#12 $\rightarrow$ \#10を切 り離し, 変電所＃100分割母線を接続する。従って, 二次切換数仕 2 であり，との操作尤って は $10.0 \mathrm{pu}$ になる。

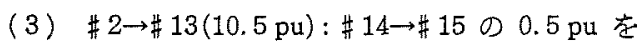

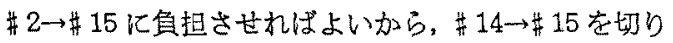


離し, 变電所井 15 の分割母線を接続する。従って, 二 次切換数は 2 であり，ての操作によって $10.0 \mathrm{pu}$ にな。

このようにして $30.0 \mathrm{pu}$ の場合の二次切換数は $2 \times$ $3=6$ となる。以上の操作により, 各送電線の潮流を それぞれの技術的送電容量内に㧕え，在来送電線のみ で全需要を一時的にまかなえる冒通しを得た。しか し，信頼度上の送電容量を越えている送電線が数多く 存在玄るので，との在来系統のみで平常洔の送電を続 けることは無理である。突合せ位置を変えて極低温送 電線の潮流を $30.0 \mathrm{pu}, 27.0 \mathrm{pu}$ ，および $24.0 \mathrm{pu}$ にし たときの系統操作数を表 4 亿ま之めておく。

以上の検討加ら一次，二次切換数上いった観点から すれば $24.0 \mathrm{pu}$ (b)および $27.0 \mathrm{pu}$ (b)の場合が有 利である。このうち平常時の送電損失が小さいという ととあ考台合わせると，27.0 pu（b)の方が有利であ るということができる。このような検討を通じて，極 低温抵抗ケーブルは，経済的には文朝20ようによよ そ $3,000 \mathrm{MW}$ から存在意義があるとされているが, 䒺統輌成わよびその運用の面からもとのモデル系統程 度の電力消費地に㿟入する価値のあるととが分った。

\section{6. 結論}

将来, 極低温送電線のような大容量高密度の送電線 が導入されたとさの都市送電系統の構成のあり方につ いて一つの技術的な概念を提案した。具体的に名古屋 地区程度の需要規模のモデル都市を想定した。この地 区における従来様式の $275 \mathrm{kV}$ およひ $154 \mathrm{kV}$ の電力 供給網モデルとして，実態調查結果から得られた将莱 予测と著しくは逸脱しない形態のものを想定した。そ れに基づいて次のような都市送電形態について検討し to

（1）約 1/4 世紀㣪の想定需要 $(8,400 \mathrm{MW})$ は想定 した彷来様式のケーブル系統のみでは供給できない。 ここに極低温送電線の導入が予想される。ここで， 臨海工業地域に存在する大容量火力発電所加ら全長約
$20 \mathrm{~km} の 275 \mathrm{kV}$ 極低温抵抗ケーブルによって一誉に $3,000 \mathrm{MW}$ の電力艺都市中心部へ送笔すること想 定した。これは玲却のための電力消費志低くおさえる ために火力永電所に蹸接する巨大な LNG 基地の泠媒 を利用することを背景としている。

（2）都市中心部へ送り这れた巨大な電力は，都 市周辺部へ逆送される系統棈成亡する。これを可能に するため都市周边部の変電所の一部を, 常時は分割さ れている複母線にそ机ぞれ内側と外側から供給される 電力を受電するいわゆる突合せ変電所とする。このよ うな系統について平常の最大負荷時の送電損失を計算 した。

（3）極低温送電線は抵抗方式にしろ高価であるか ら1回線のみを設置し，てれが故障した場合には突合 せ变電所の分割母線を接続し，外周加電力を送る方 式を提案した。乙れは従来送電線の技術的送笔容置乙 信頼度上の送笔容量との間の余裕分を全面的に利用す る香のである。

(4) 平常時の送電損失, 極低温送電線事故時の系統 操作数の两面から，とのモデル系統に和いては極低温 龇抗ケーブルに $2,700 \mathrm{MW}$ 程度の潮流をのせるのが よいととが導かれた。

終りに，本研究は昭和 59 年文部省科学研究 㭪 助金 エネルギー特別研究（No. 59045069）の補助を受けた とと，および，計算は名古孱大学大型到算機センター で行なったととを記して感謝の意を表します。

(昭和 60 年 6 月 26 日受付, 同 60 年 11 月 11 日再受付)

\section{文献}

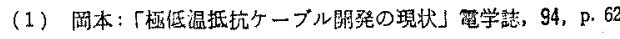
(昭 49-5)

（2）获池・岩田・木下:「送電線路におりる省資愿・省エネルギ 一対策」昭 55 霟気学会全大, S. 3-21（昭 55)

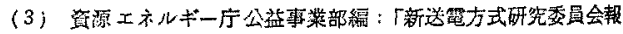
告」 P. 114 (昭 50)

(4) P. Ailleret: "Consequence Economique D'UN Ecart De La Tension Par Rapport a La Tension Optimun", CIGRE 1960, No. 416 